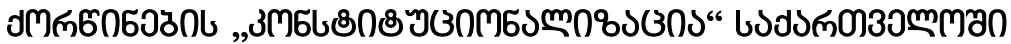

\section{I. zolozomo}

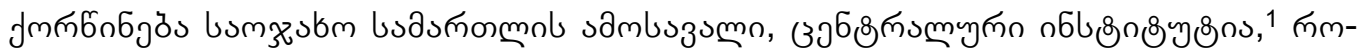

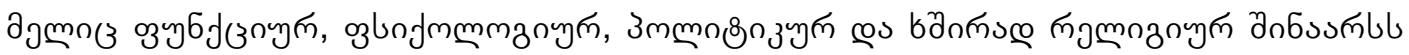

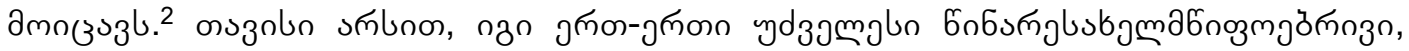

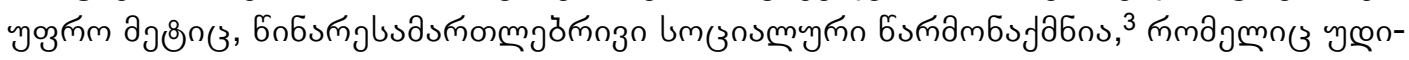

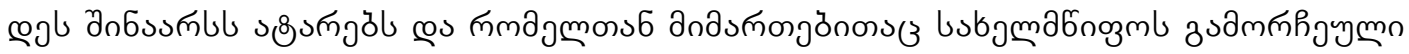

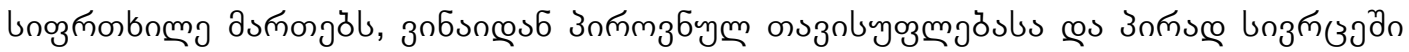

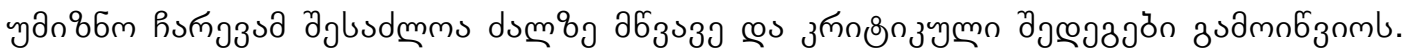

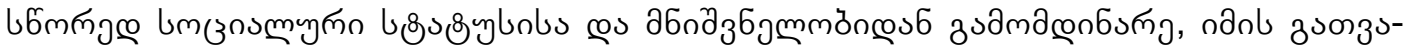

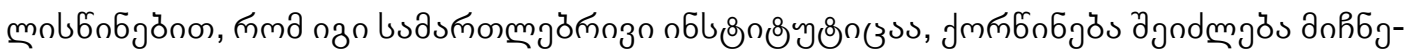

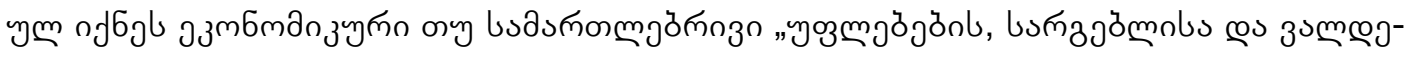

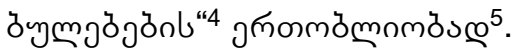

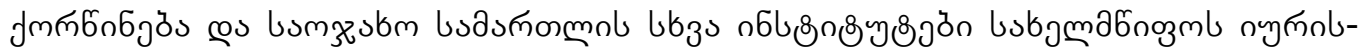

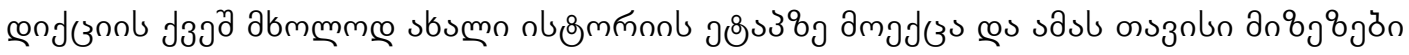

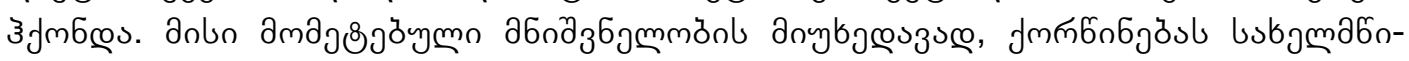

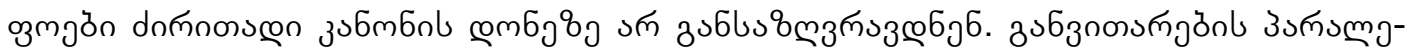

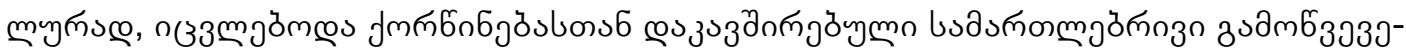

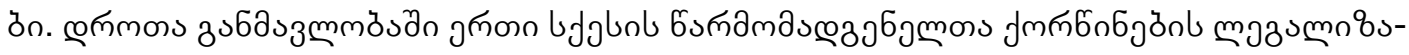

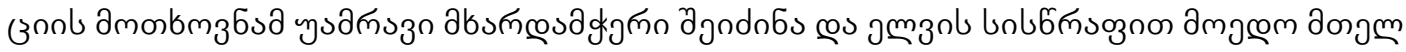

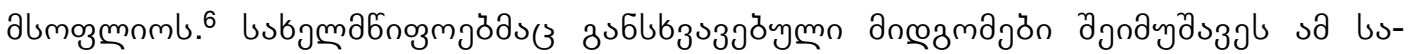

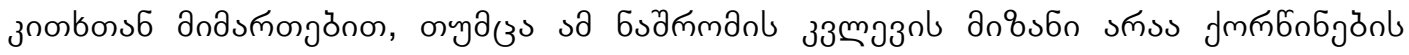

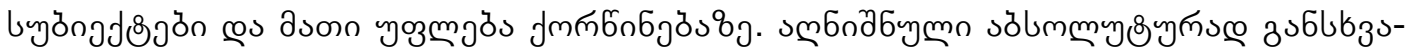

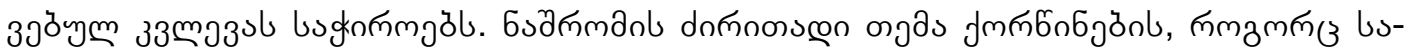

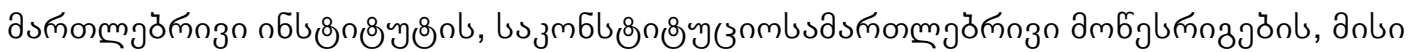

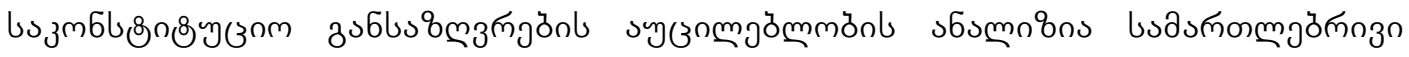

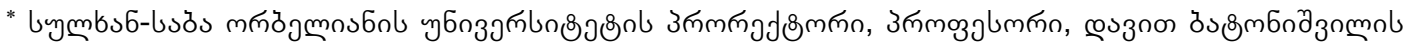

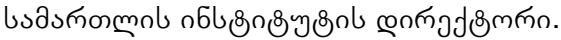

1 Herring J., family Law, $4^{\text {th }}$ Ed., Pearson Longman, 2009, 37.

2 ob., $\cap$ ग3 3 , 40-41.

3 Wardle L.D., The Attack on Marriage as the Union of a Man and Woman, North Dakota Law Review, Vol.83, 2007, 1370.

${ }^{4}$ nb., Eskridge W.N., The Case for Same-Sex Marriage: From Sexual Liberty to Civilized Commitment, 1996, 70.

${ }^{5}$ Kristen E., The Struggle for Same-Sex Marriage Continues, Berkeley Women's Law Journal, Vol. 14, No. 1, 1999, 104-105.

${ }^{6}$ Wardle L.D., The Attack on Marriage as the Union of a Man and Woman, North Dakota Law Review, Vol. 83, 2007, 1368.
} 


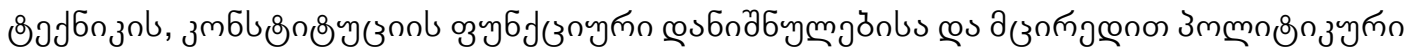

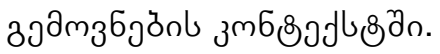

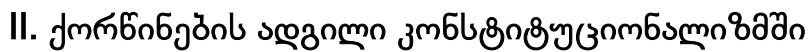

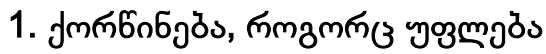

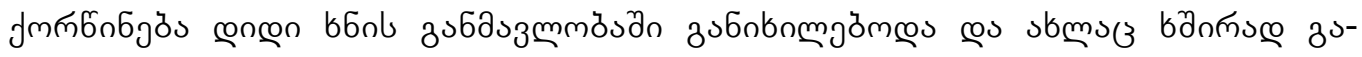

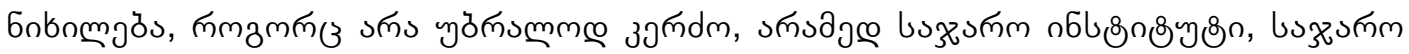

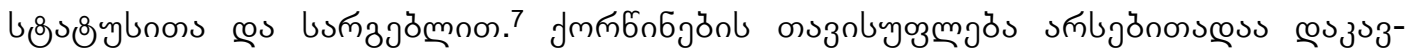

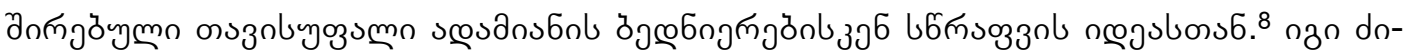

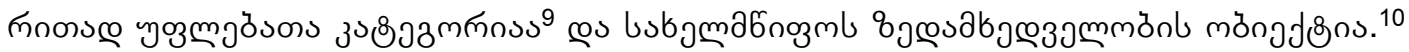

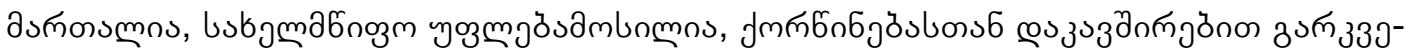

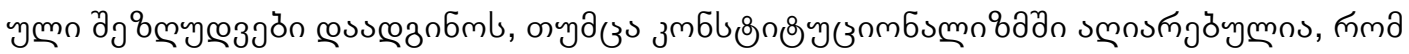

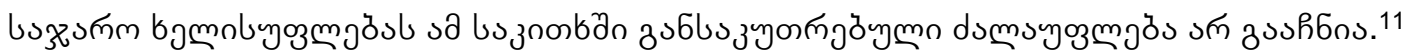

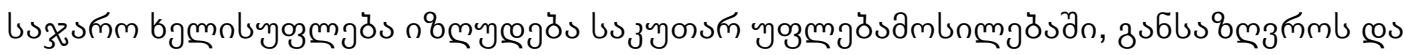

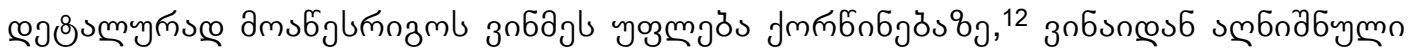

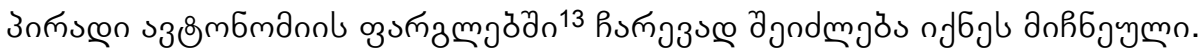

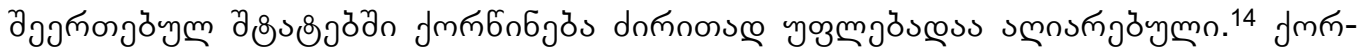

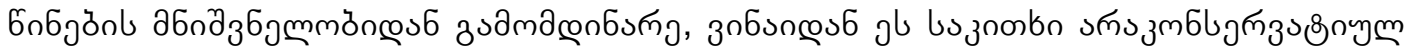

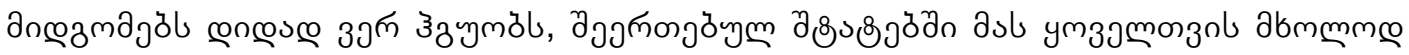

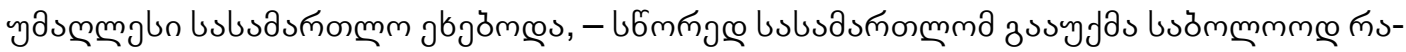

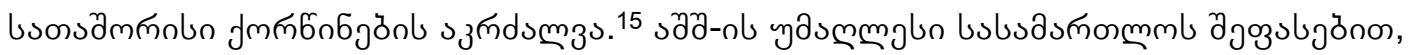

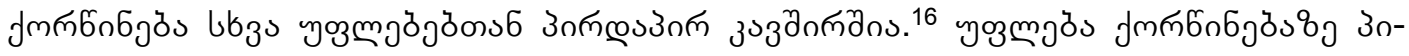

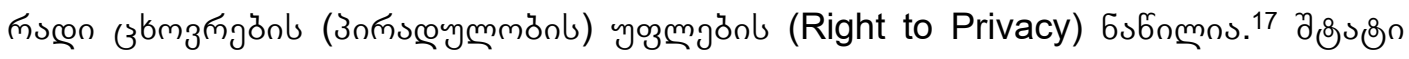

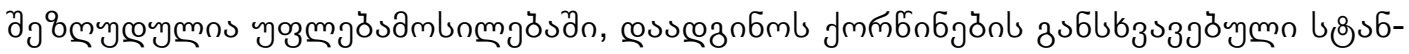

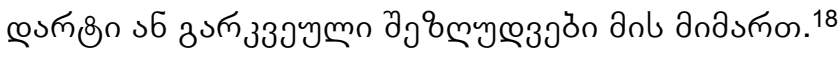

\footnotetext{
7 Maynard v. Hill, 125 U.S. 190, 2213 (1888).

8 Loving v. Virginia, 388 U.S. 13 (1967).

9 Zablocki v. Redhail, 434 U.S. 78 (1978); Skinner v. Oklahoma, 316 U.S. 535, 541 (1942).

10 Maynard v. Hill, 125 U.S. 190, 205 (1888), Kristen E., The Struggle for Same-Sex Marriage Continues, Berkeley Women's Law Journal, Vol. 14, No. 1, 1999, 105.

11 Turner v Safley, 428 U.S. 95 (1987).

12 Statsky W.P., Family Law, $5^{\text {th }}$ Ed., West Thomson Learning, 2002, 117.

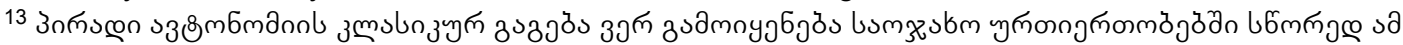

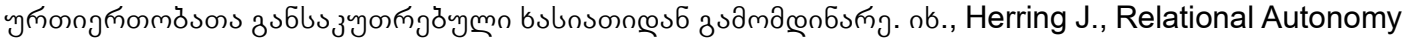
and Family Law, in: Rights, Gender and Family Law, Edited by J. Wallbank, Sh. Chaudhry, J. Herring, Routledge, 2010, 262-263.

14 Statsky W.P., Family Law, $5^{\text {th }}$ Ed., West Tomson Learning, 2002, 117.

15 nb., Kristen E., The Struggle for Same-Sex Marriage Continues, Berkeley Women's Law Journal, Vol. 14, No. 1, 1999, 115.

${ }^{16}$ Family Law, Issues, Debates, Policy, Edited by J. Herring, William Publishing, 2001, 9; Loving v. Virginia, 388 US 1 (1967).

17 Griswold v. Connecticut, 381 US 479 (1965).

18 Statsky W.P., Family Law, $5^{\text {th }}$ Ed., West Tomson Learning, 2002, 117.
} 


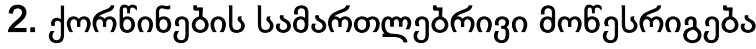

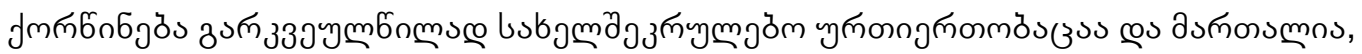

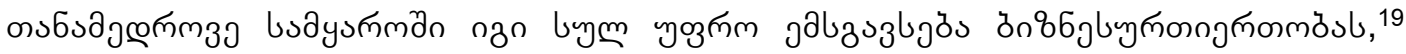

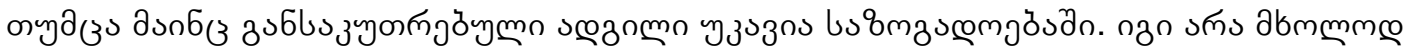

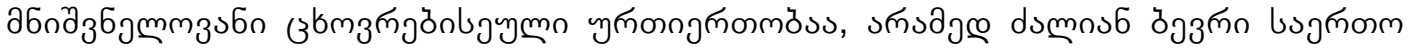

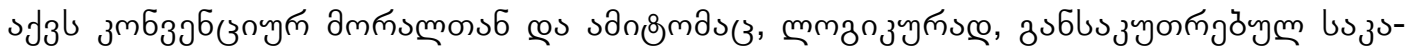

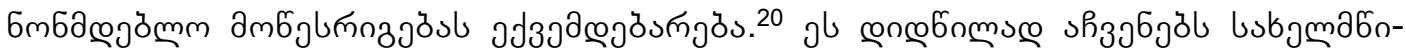

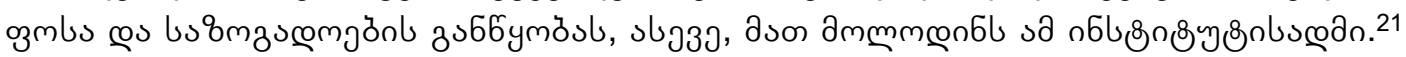

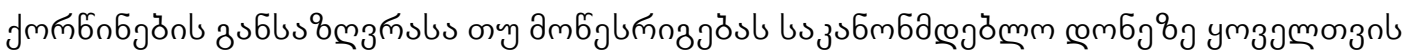

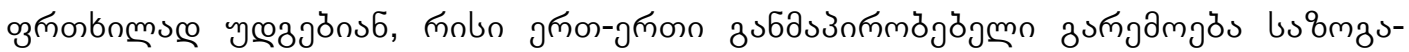

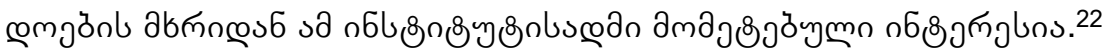

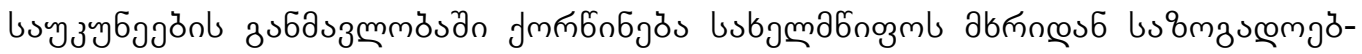

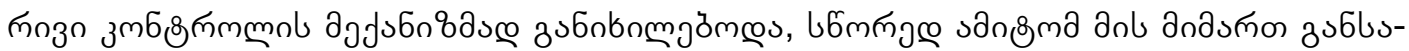

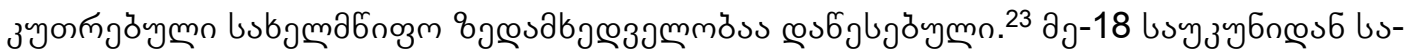

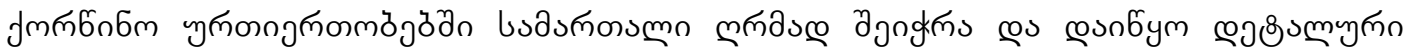

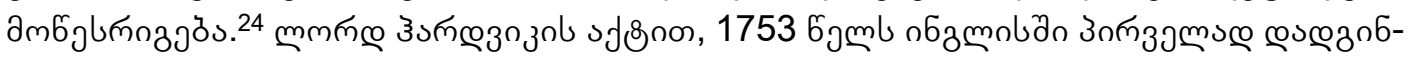

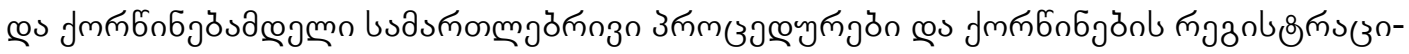

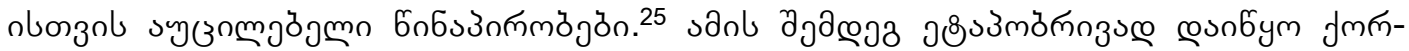

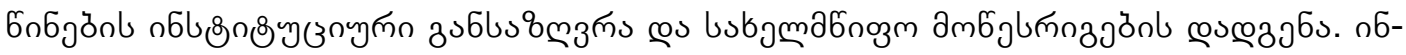

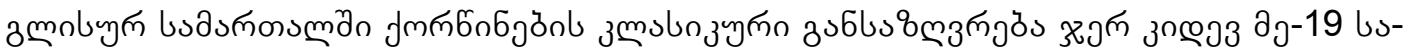

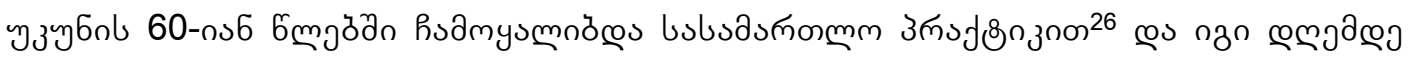

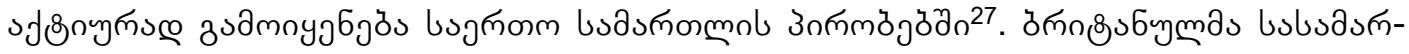
мммmј

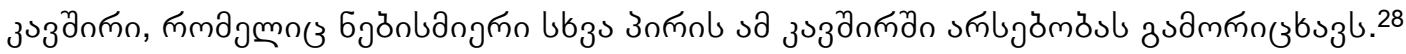

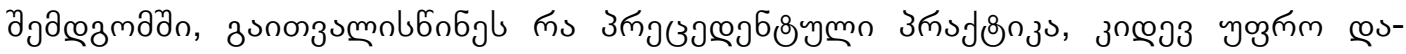

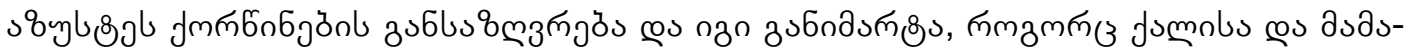

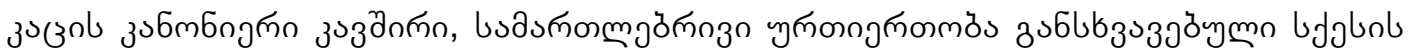

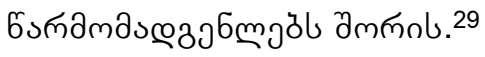

\footnotetext{
${ }^{19}$ Katz S.N., Family Law in America, Oxford University Press, 2003, 37.

20 ob., Maynard v. Hill, 125 U.S. 205 (1888).

21 Wardle L.D., The Attack on Marriage as the Union of a Man and Woman, North Dakota Law Review, Vol. 83, 2007, 1370.

22 กj30, 1369; Stewart M.N., Genderless Marriage, Institutional Realities, and Judicial Elision, Duke Journal of Constitutional Law and Public Policy, Vol. 1, No. 1, 2006, 3.

23 Family Law and Family Values, Edited by M. Maclean, Hart Publishing, 2005, 29.

${ }^{24}$ Rodgers ME., Understanding Family Law, Cavendish Publishing, 2004, 1.

25 ก $330,2$.

26 Hyde v. Hyde and Woodmansee, [L.R.] 1 P. \& D. 130 (1866).

27 ob., Dalby R., Essential Family Law, $2^{\text {nd }}$ Ed., 2001, 3.

28 nb., Curzon L.B., Briefcase on Family Law, $2^{\text {nd }}$ Ed., Cavendish Publishing, 2001, 1.

29 nb., Chaidan v. Godin-Mendoza [2004] UKHL 30. Curzon L.B., Briefcase on Family Law, $2^{\text {nd }}$ Ed., Cavendish Publishing, 2001, 1; Hyde v. Hyde and Woodmansee, [L.R.] 1 P. \& D. 130 (1866).
} 


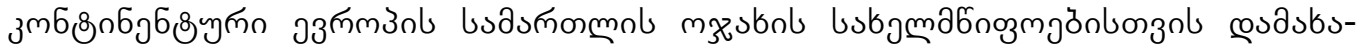

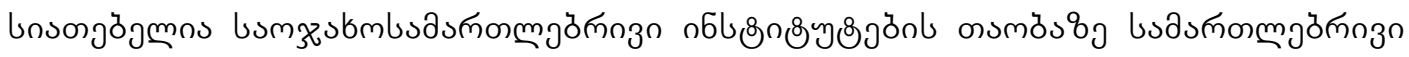

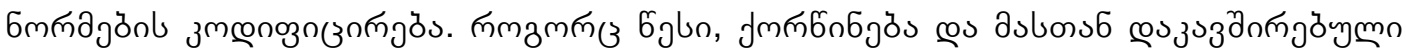

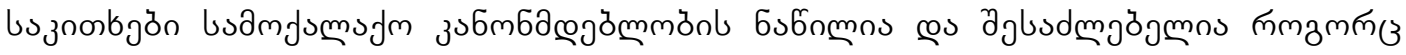

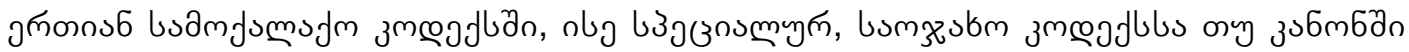

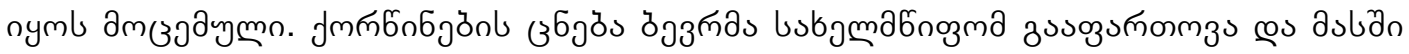

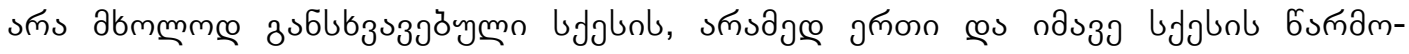

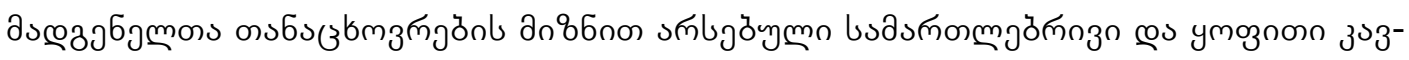

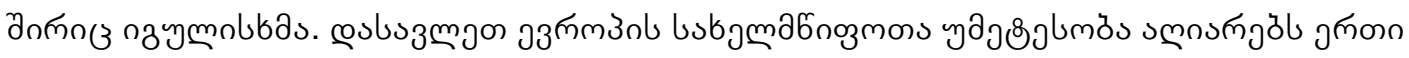

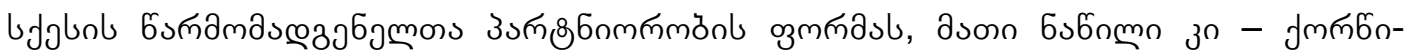

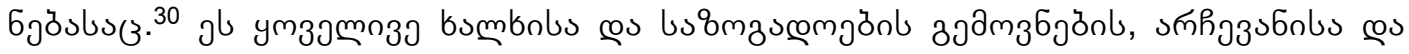

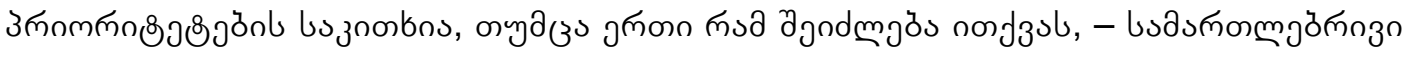
пзدmbs

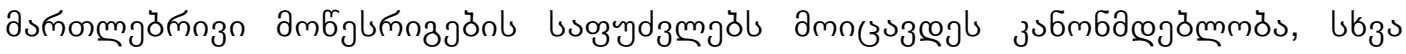

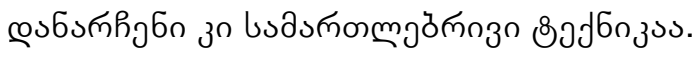

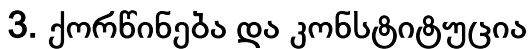

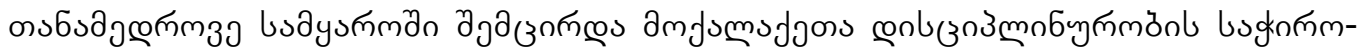

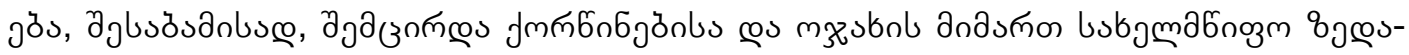

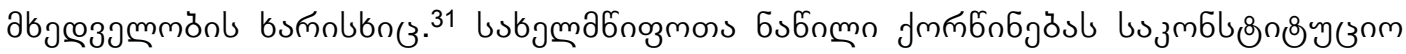

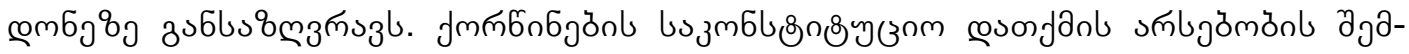

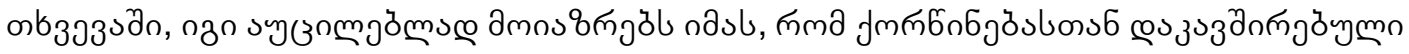

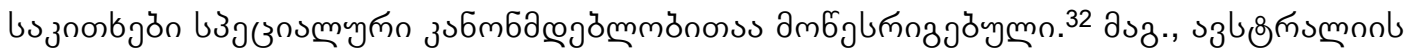

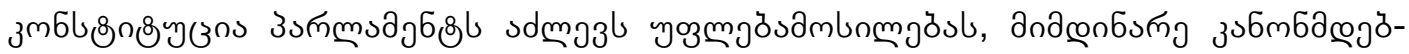

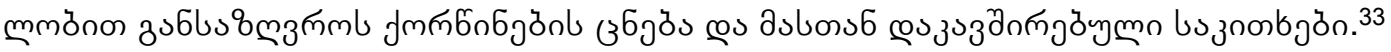

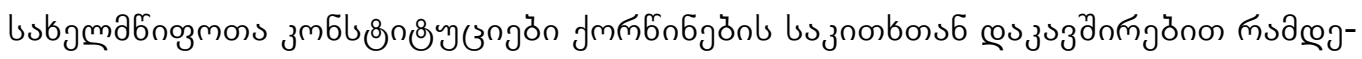

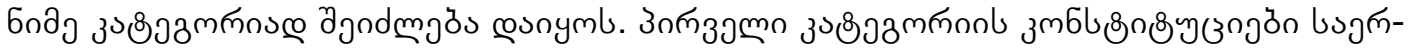

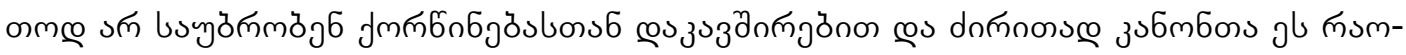

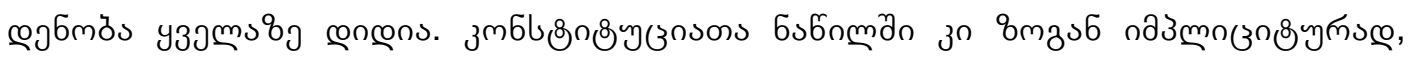

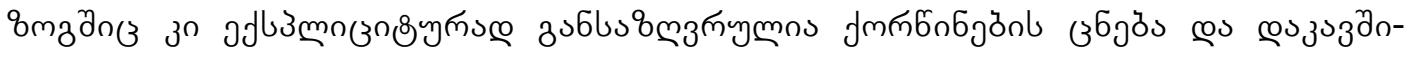

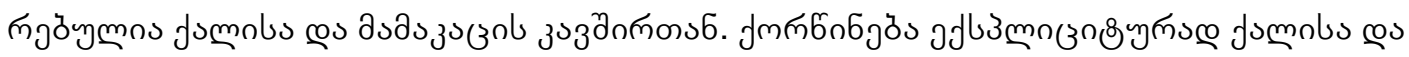

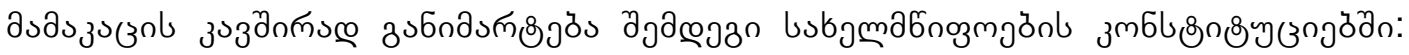

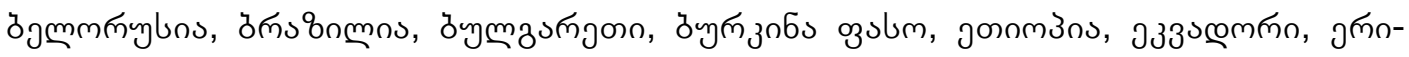

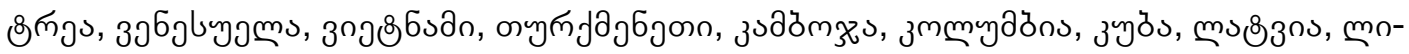

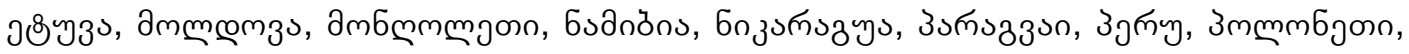

30 Casto W.R., Our Unwritten Constitution and Proposals for a Same-Sex Marriage Amendment, Creighton Law Review, Vol. 38, 2005, 278.

31 nb., Family Law and Family Values, Edited by M. Maclean, Hart Publishing, 2005, 29.

32 ob., Dalby R., Essential Family Law, ${ }^{\text {nd }}$ Ed., 2001, 2.

33 กป3ว. 


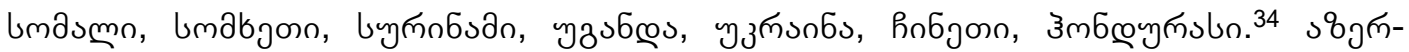

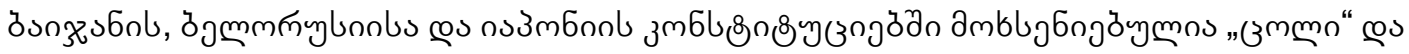
"ปаงกั". 35

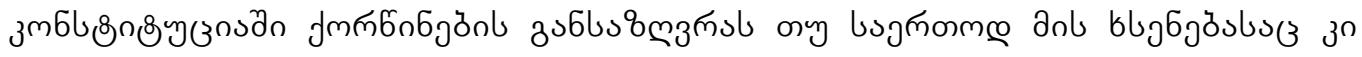

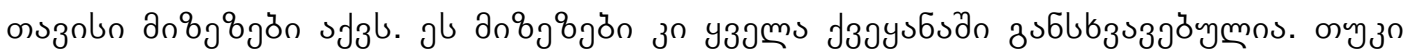

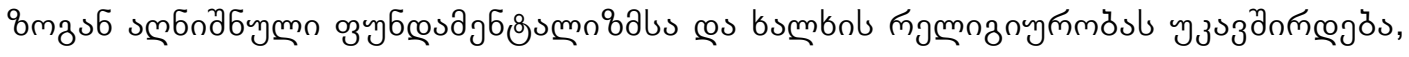

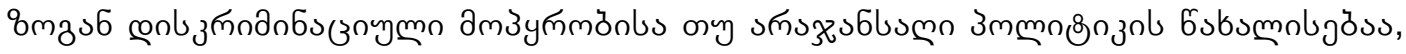

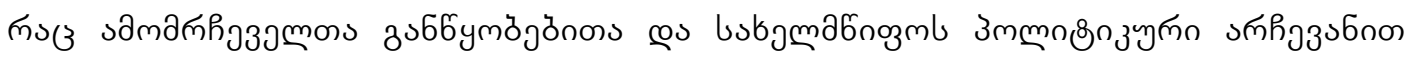

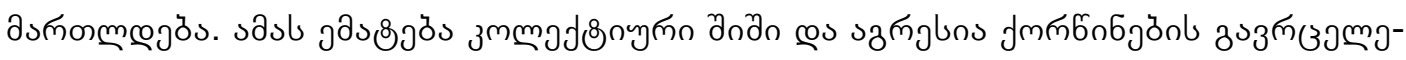

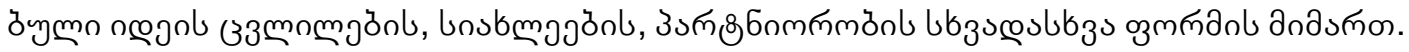

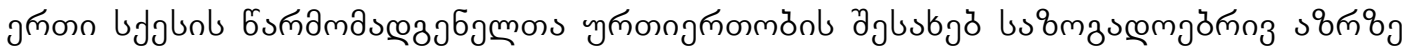

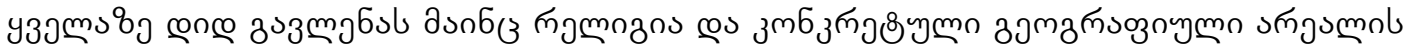

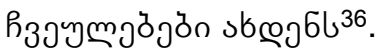

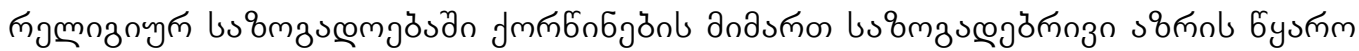

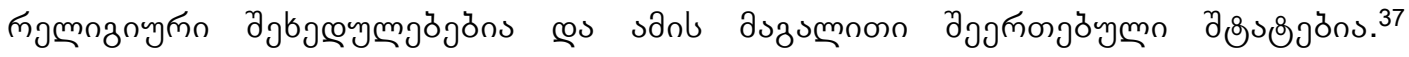

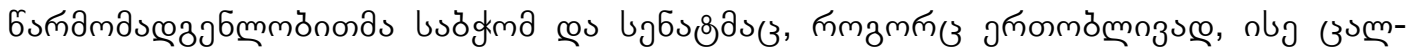

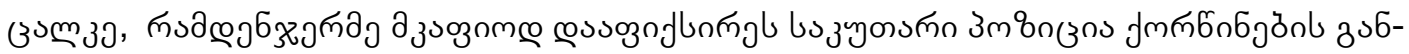

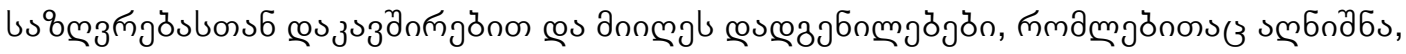

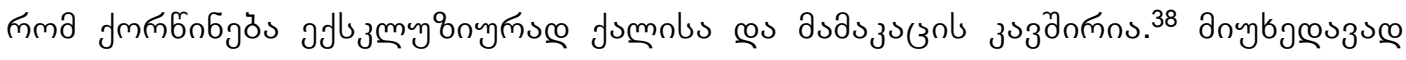

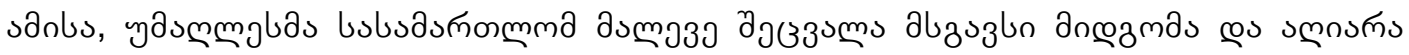

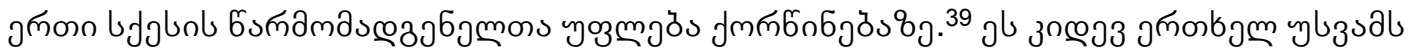

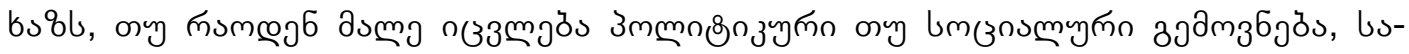

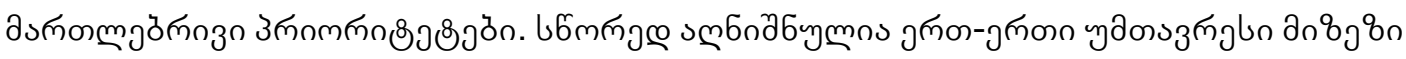

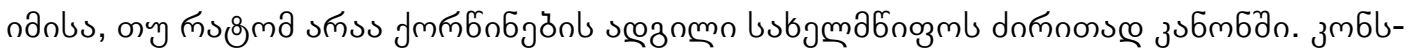

${ }^{34}$ Constitution of the Republic of Belarus, Art.32, Constitution of the Federal Republic of Brazil, Art.226 (3), Constitution of the Republic of Bulgaria, Art.46, Constitution of Burkina Faso, Art.23, Constitution of the Federal Republic of Ethiopia, Art.34 (1) and Art.35 (2), Constitution of the Republic of Ecuador, Art.67, Constitution of the State of Eritrea, Art.22 (3), Constitution of the Republic of Venezuela, Art.77, Constitution of Socialist Republic of Vietnam, Art.36 (1), Constitution of the Republic of Turkmenistan, Art.25, Constitution of the Kingdom of Cambodia, Art.45, Constitution of the Republic of Colombia, Art.42, Constitution of the Republic of Cuba, Art.36 and Art.44, Constitution of the Republic of Latvia, Art. 110, Constitution of the Republic of Lithuania, Art.38, Constitution of the Republic of Moldova, Art.48 (2), Constitution of Mongolia, Art.16 (11), Constitution of the Republic of Namibia, Art.14 (1), Constitution of the Republic of Paraguay, Art.50, Art.51 and Art.52, Constitution of the Republic of Peru, Art.5, Constitution of the Republic of Poland, Art.18, Constitution of the Republic of Nicaragua, Art.72, Constitution of the Republic of Armenia, Art.35, Constitution of the Federal Republic of Somalia, Art.28 (5), Constitution of the Republic of Suriname, Art.45 (2), Constitution of the Republic of Uganda, Art.31 (1), Constitution of the Republic of Ukraine, Art.51, Constitution of the Peoples Republic of China, Art.42, Constitution of the Republic of Honduras, Art.112.

${ }^{35}$ Constitution of the Azerbaijan Republic, Art. 34 (4), Constitution of the Republic of Belarus, Art.32, Constitution of Japan, Art.24,

36 nb., Olson L.R., Cadge W., Harrison J.T., Religion and Public Opinion about Same-Sex Marriage, Social Science Quarterly, Vol. 87, No. 2, 2006, 342-343.

37 ก 33 , 355.

38 nb., H.R.J. Res. 56, 108 ${ }^{\text {th }}$ Cong., $1^{\text {st }}$ sess. (2003); S.J. Res. 30, 108 ${ }^{\text {th }}$ Cong., $2^{\text {nd }}$ sess. (2004).

39 nb., Obergefell v. Hodges, 576 U.S. 644 (2015). 


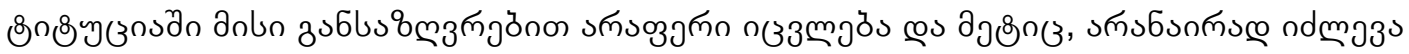

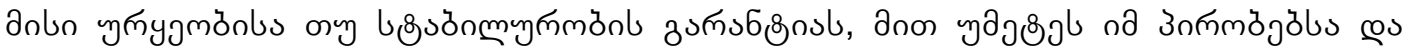

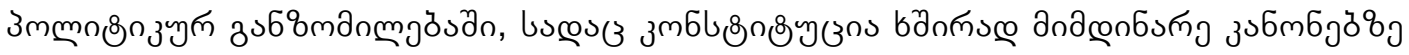

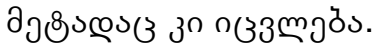

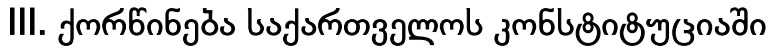

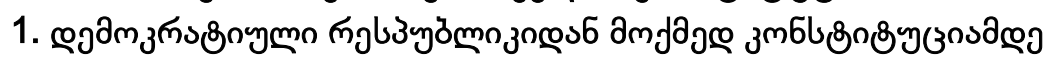

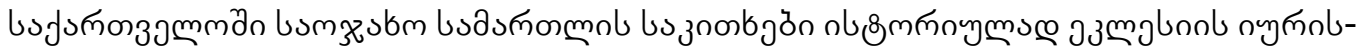

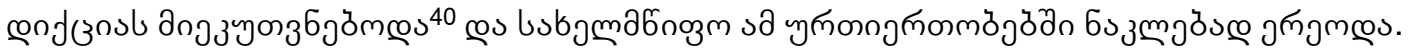

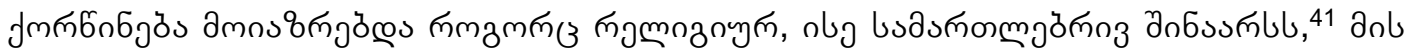

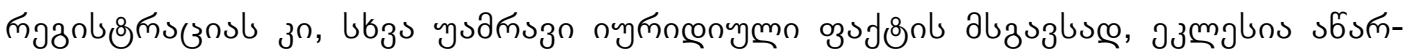
วmภว̆œง. 42

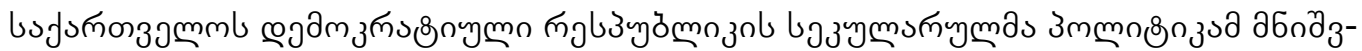

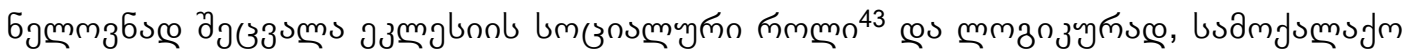

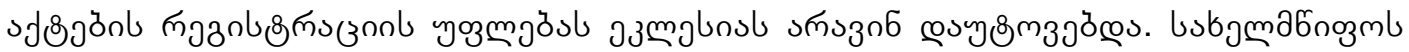

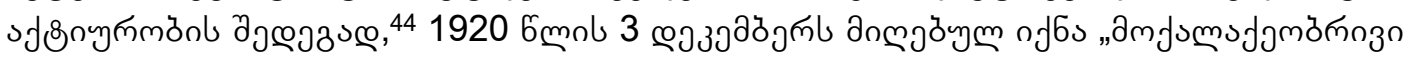

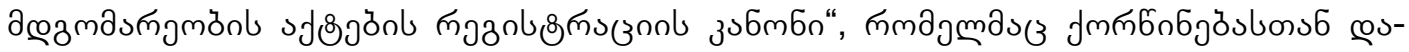

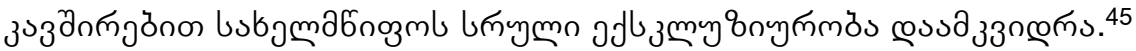

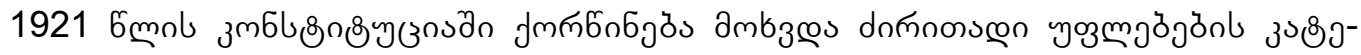

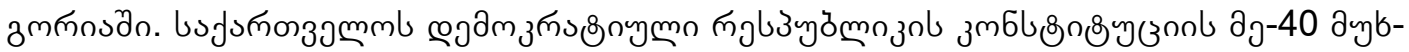

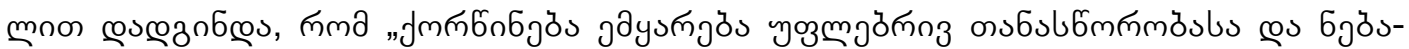

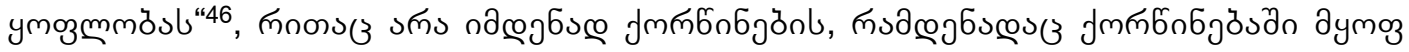

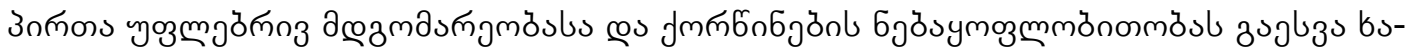

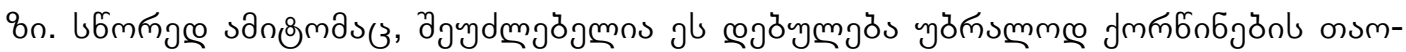

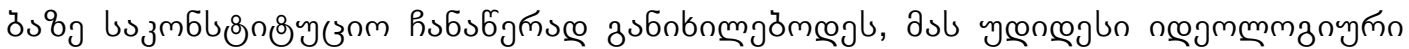

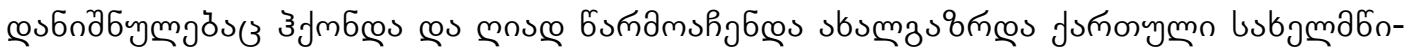

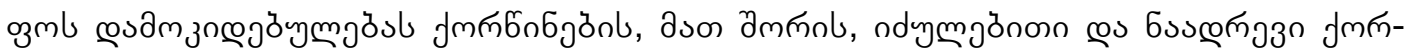

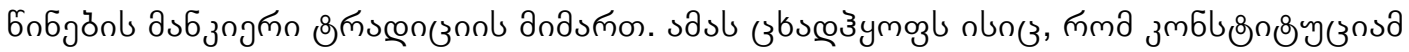

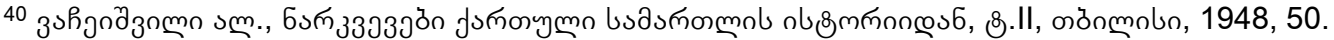

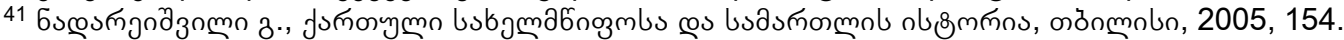

42 nb., зазабงзs œ., эз

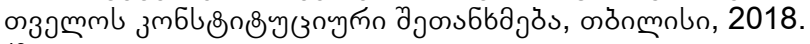

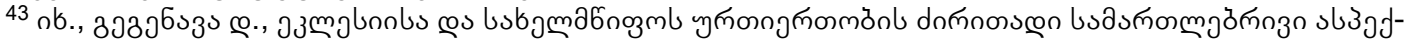

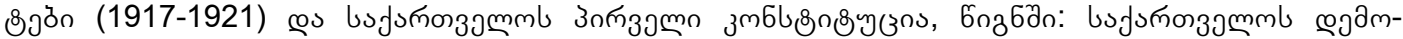

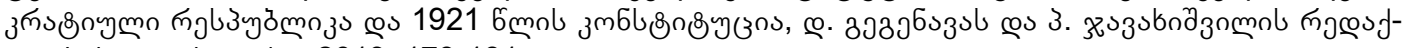

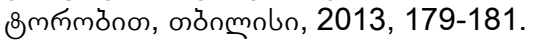

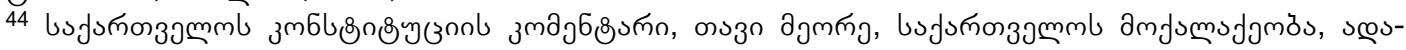

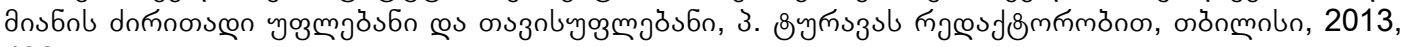
438

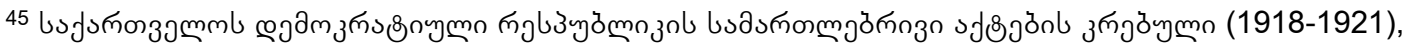
oర̉nmonun, 1990, 443-450.

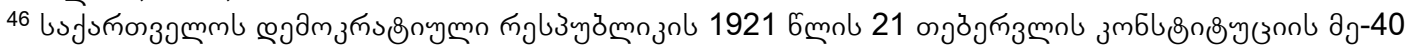

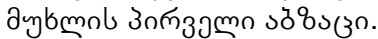




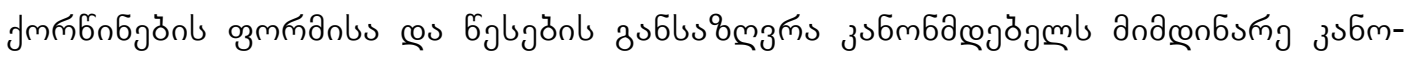

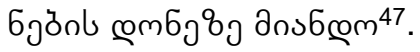

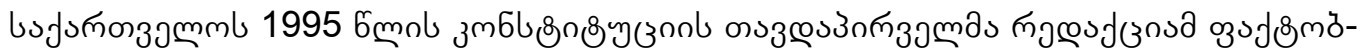

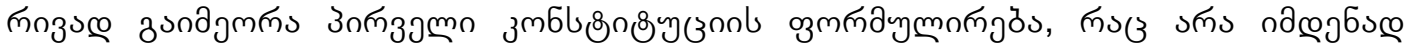

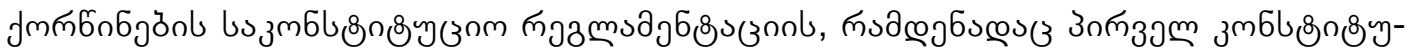

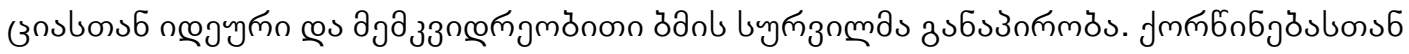

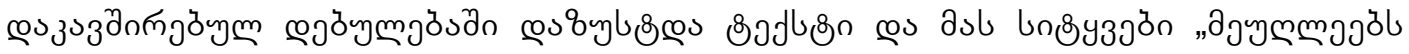

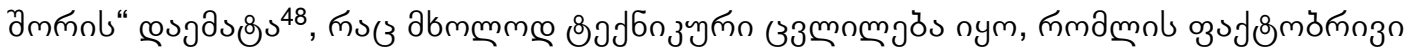

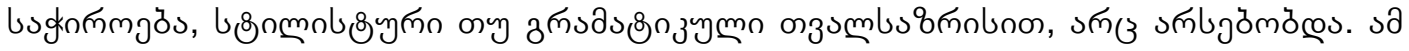

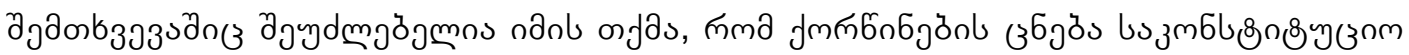

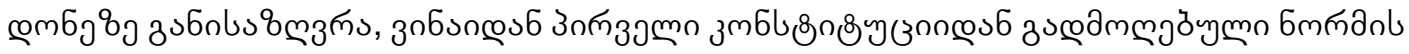

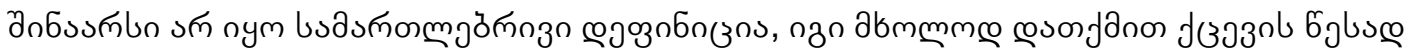

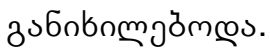

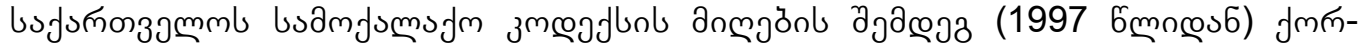

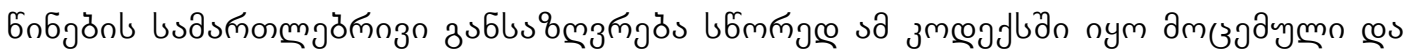

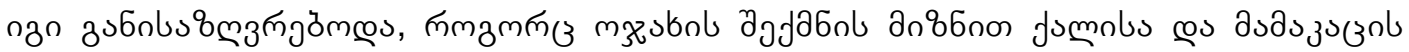

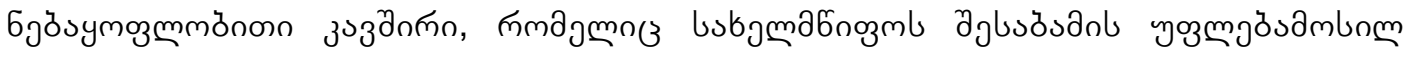

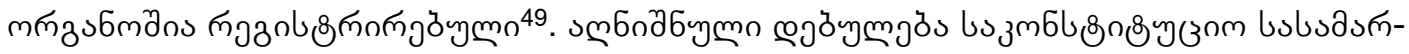

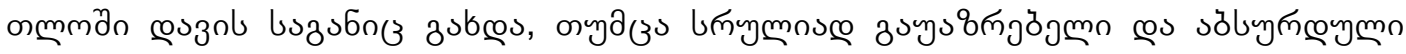

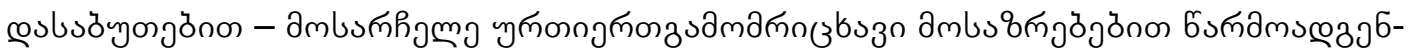

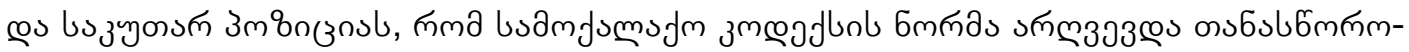

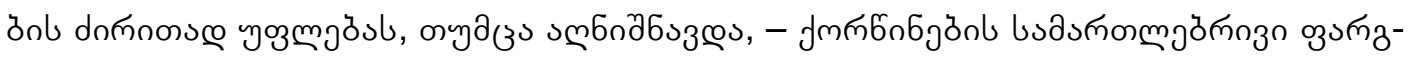

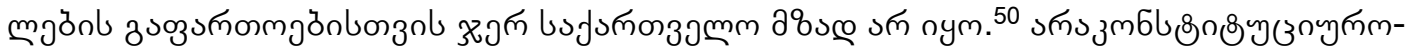

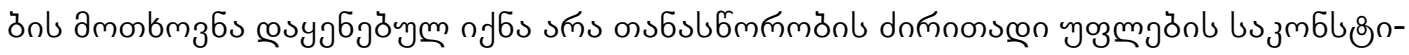

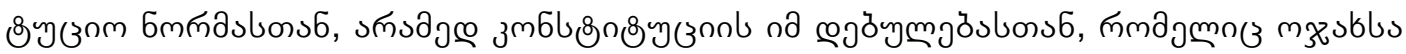

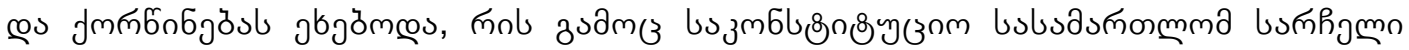

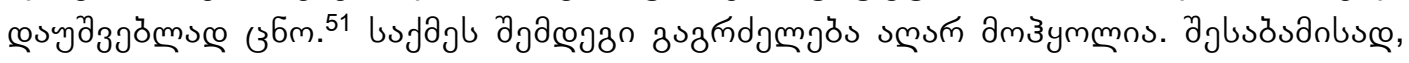

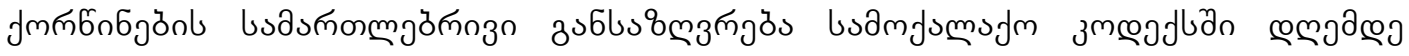

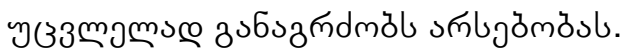

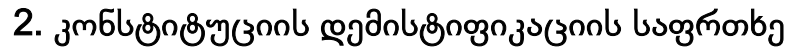

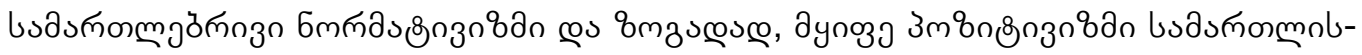

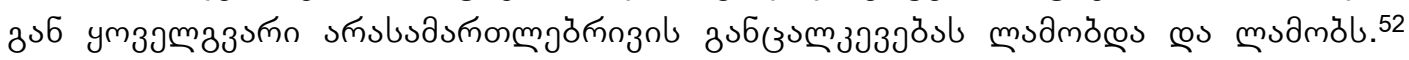

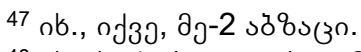

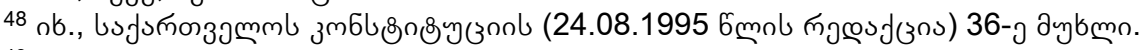

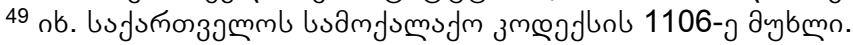

50 ob., bujunos3

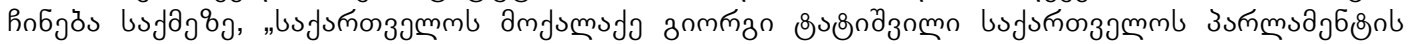
6обงsmạoว", II, 2.

51 ก
}

52 nb., Kelsen H., The Pure Theory of Law, Translated by M. Knight, Cambridge University Press, 1967. 


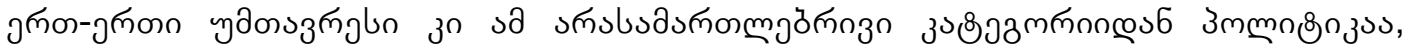

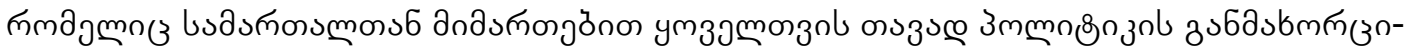

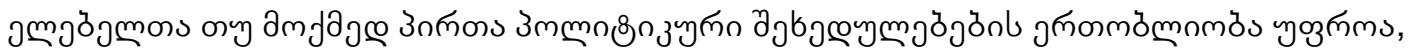

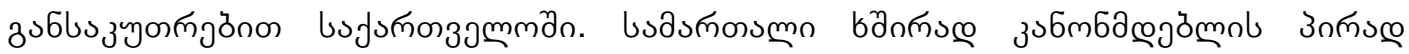

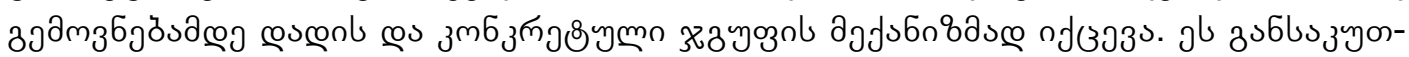

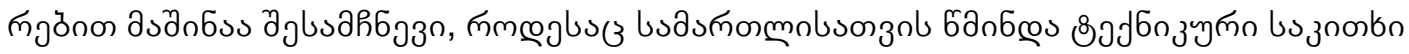

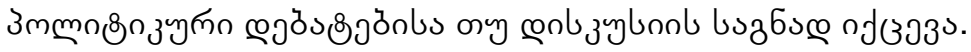

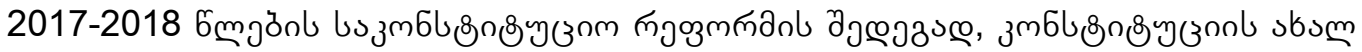

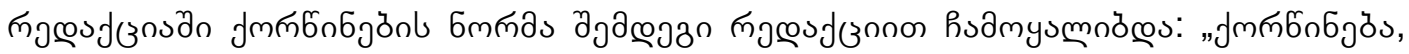

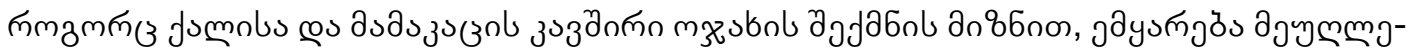

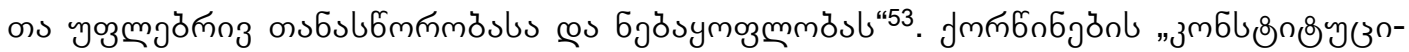

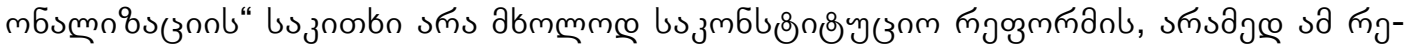

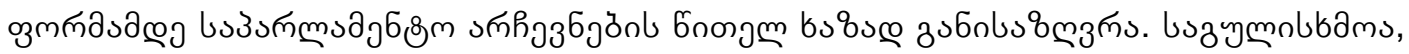

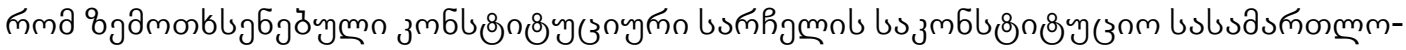

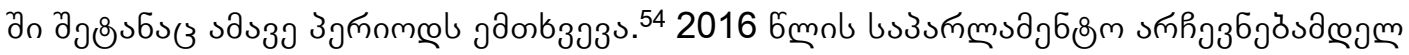

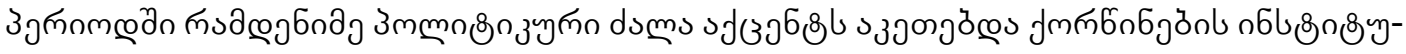

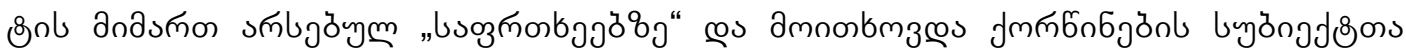

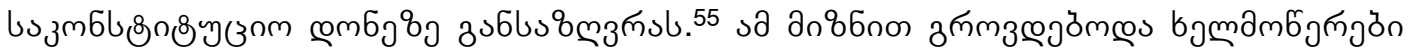

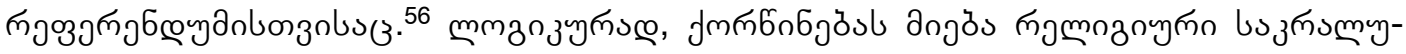

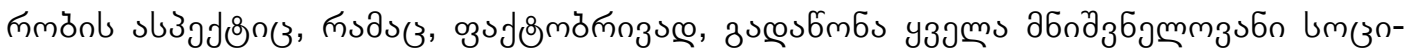

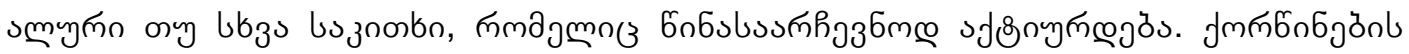

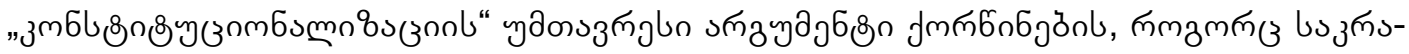

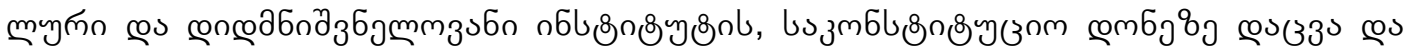

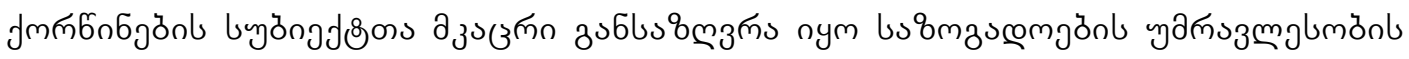

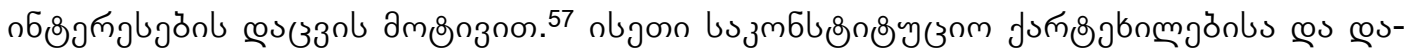

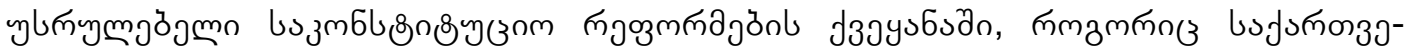

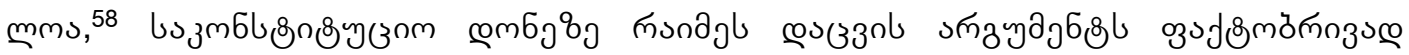

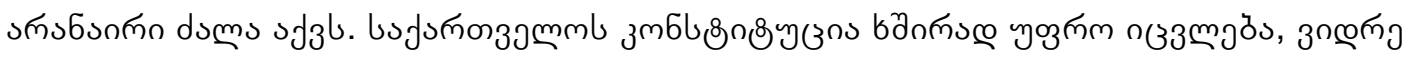

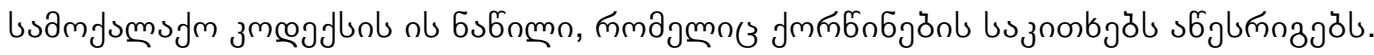

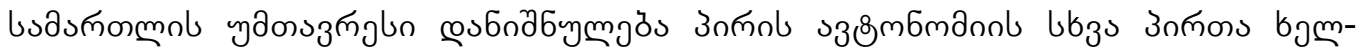

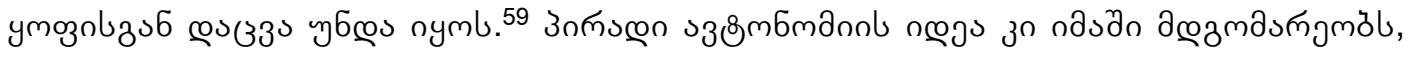

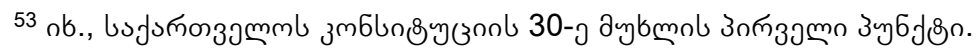

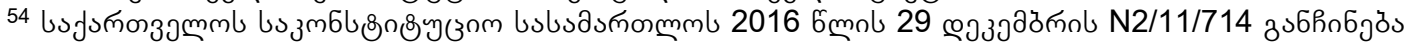

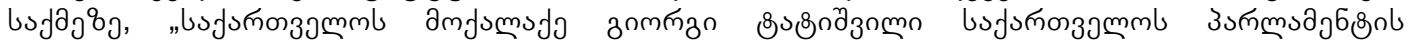
6пбоммдœо", I.

$55<$ https://netgazeti.ge/news/95104/> [20.03.2020]

$56<$ https://gdi.ge/ge/news/platforma-ara-fobias-gancxadeba-adamianis-uflebata-sakitxebze-

referendumis-danishvnis-motxovnastan-dakavshirebit.page> [20.03.2020]

57 <https://old.civil.ge/geo/article.php?id=30198> [20.03.2020]

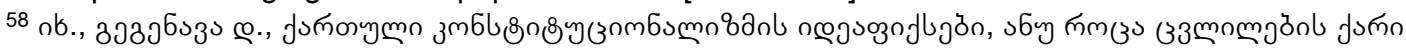

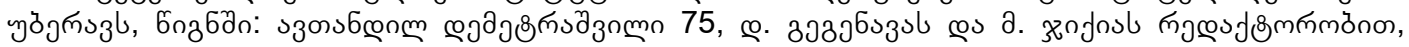
ỏ̇nmolon, 2017, 106-124.

59 Herring J., Relational Autonomy and Family Law, in: Rights, Gender and Family Law, Edited by J. Wallbank, Sh. Chaudhry, J. Herring, Routledge, 2010, 258. 


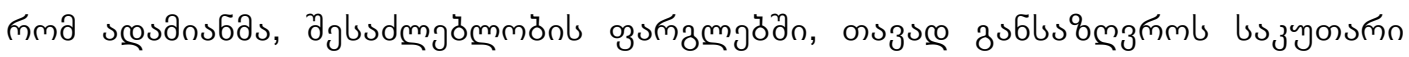

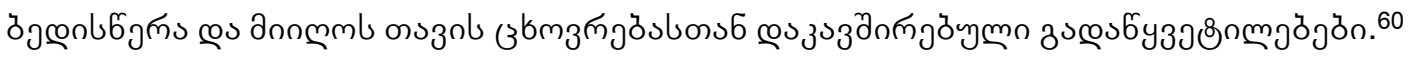

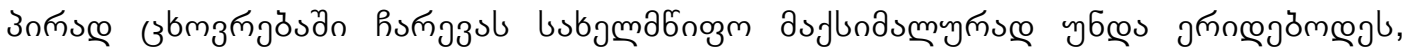

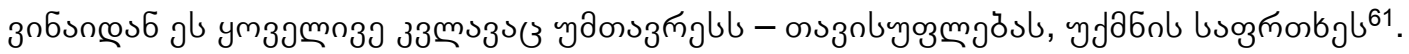

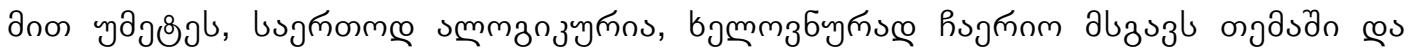

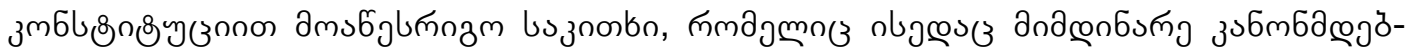

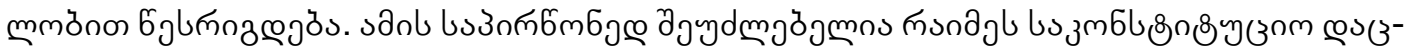

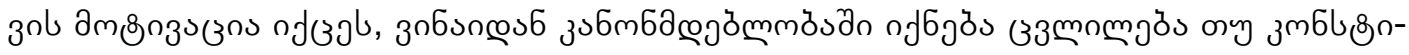

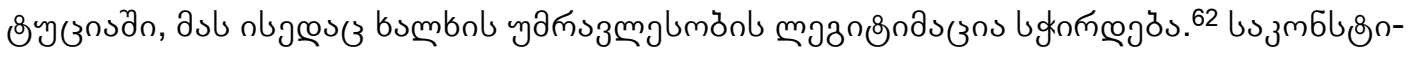

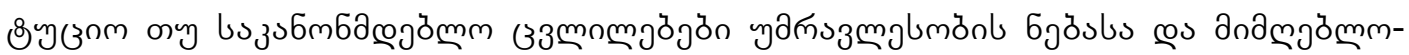

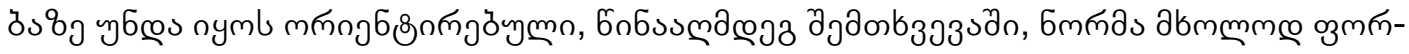

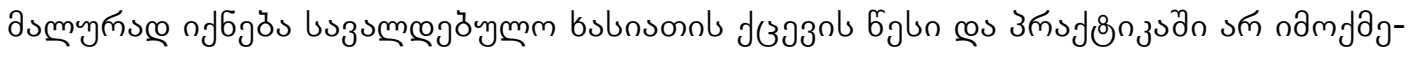

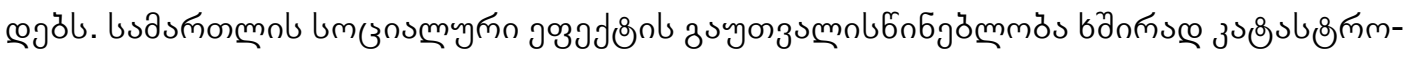

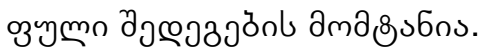

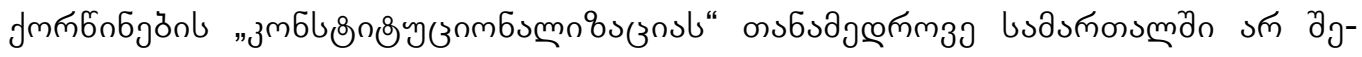

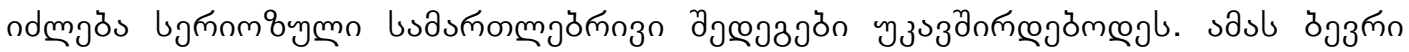

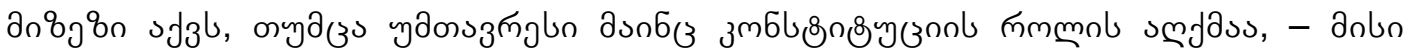

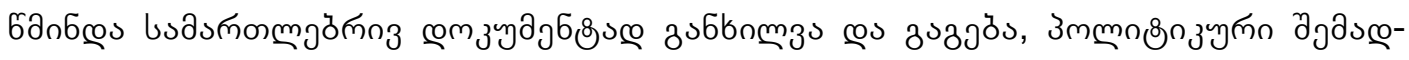

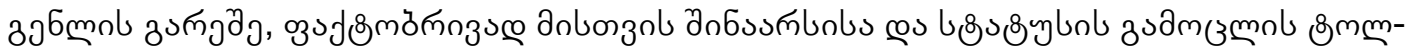

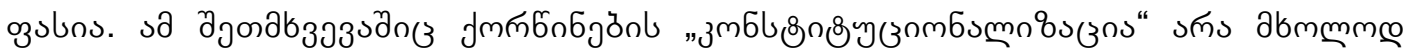

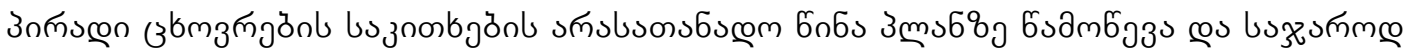

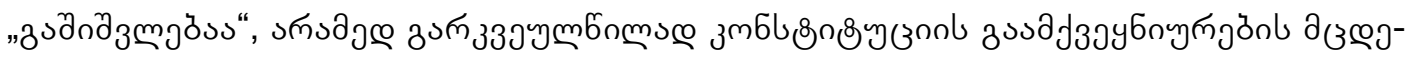

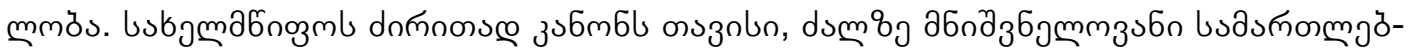

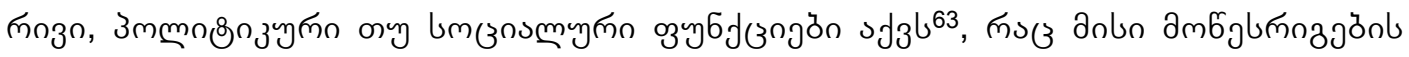

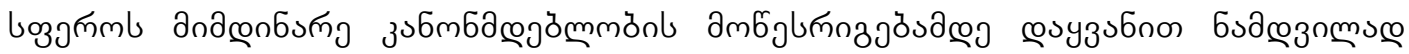

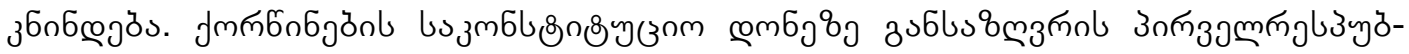

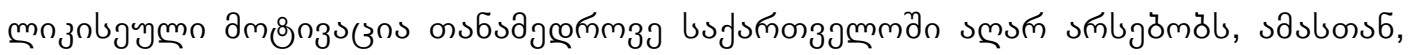

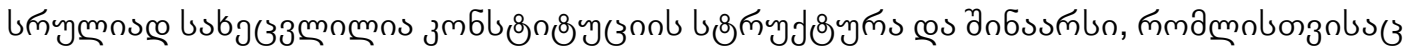

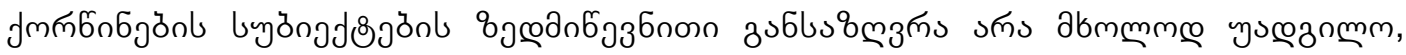

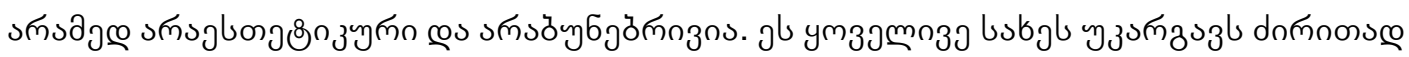

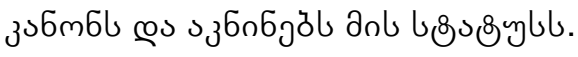

\section{IV. פobl $33^{6 s}$}

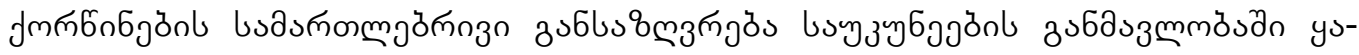

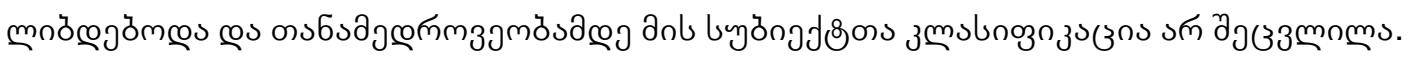

\footnotetext{
60 nb., Raz J., The Morality of Freedom, Oxford University Press, 1986, 369.

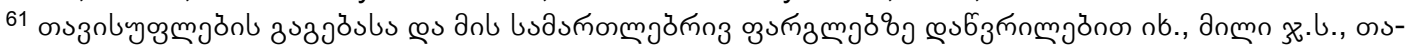

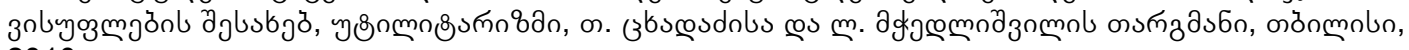
2010.

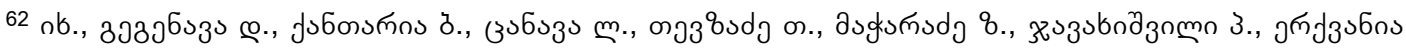

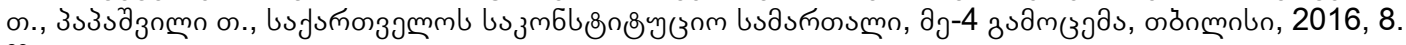
63 Barak A., Purposive Interpretation in Law, translated from Hebrew by Sari Bashi, Princeton, New Jersey, 2005, 370.
} 


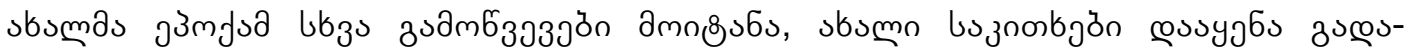

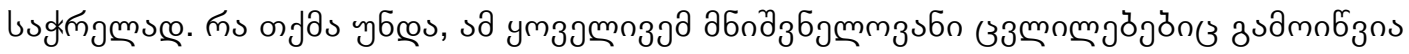

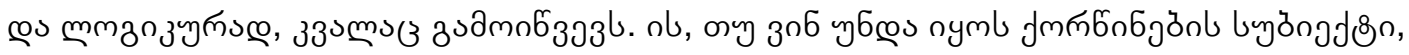

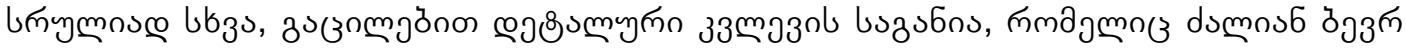

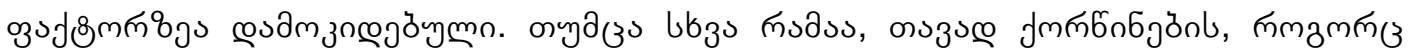

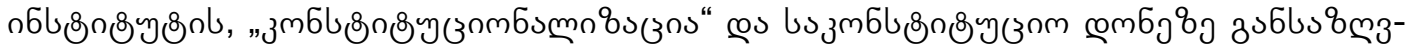

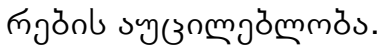

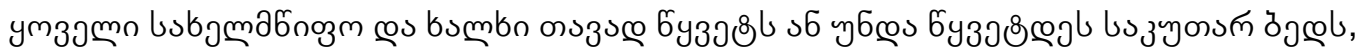

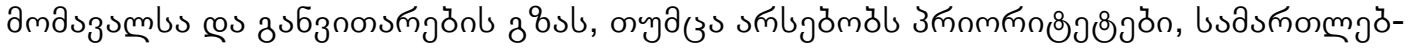

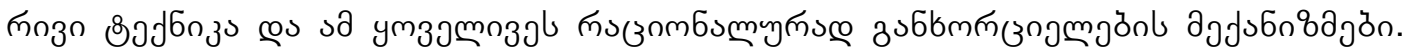

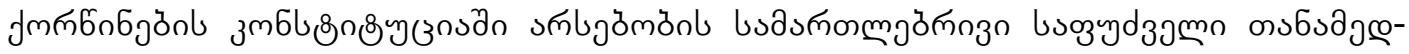

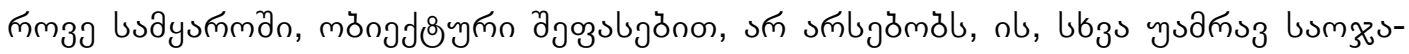

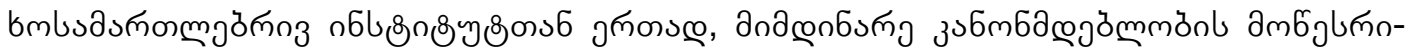

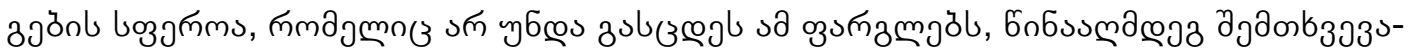

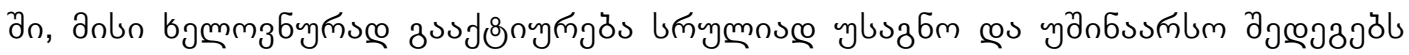

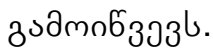

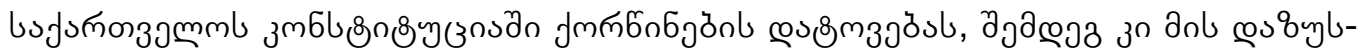

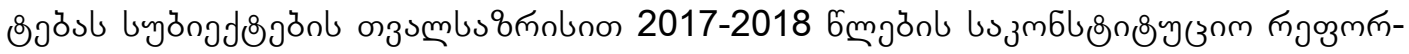

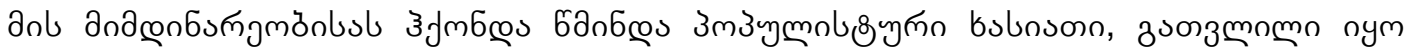

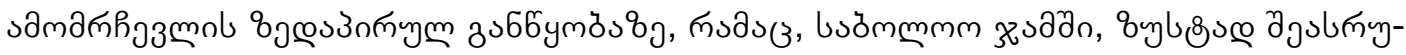
ms

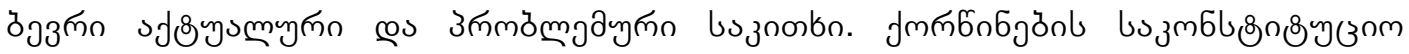

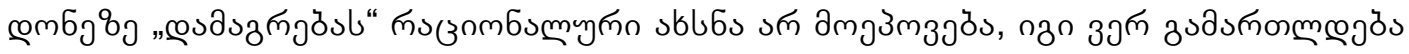

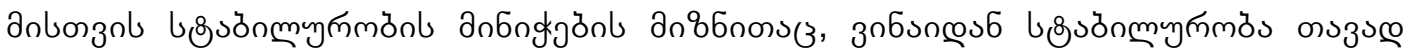

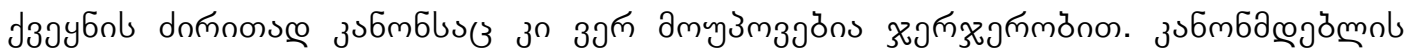
a اзzз3

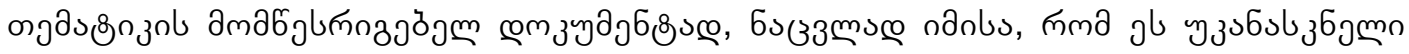

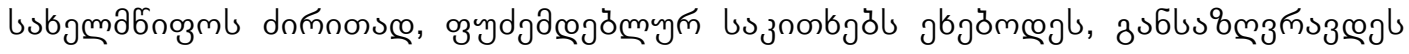

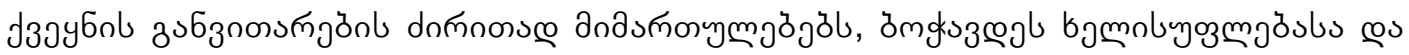

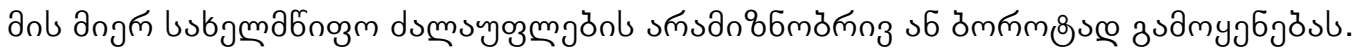

зj

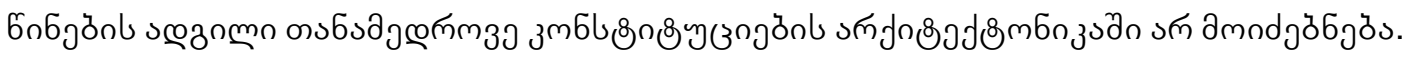

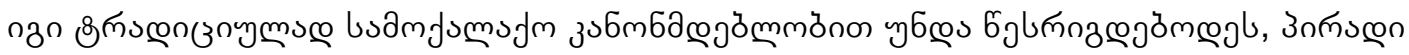

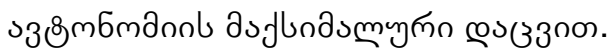

